\title{
IV. Atotitzetr.
}

\section{Berihtigung.}

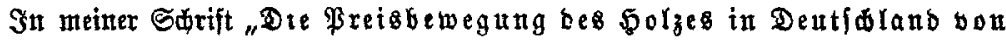

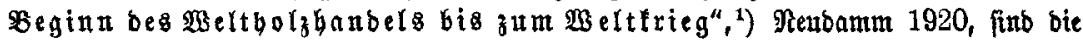
nadiftełenden zowei Srrtimer zil Eeriditigen:

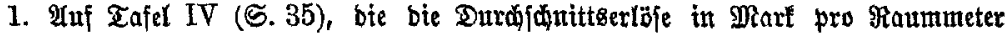
Brent= unb Rohlbol in ben Stantowalbungen Bayerns bon 1870-1912 graphija barftelft, wurben yon 1902 ab irrtïmlidiertoeife bie Durdifdnittserlöfe pro Feft meter

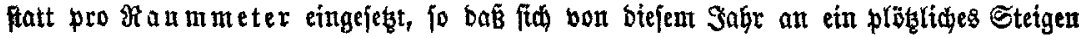
ber Brenubolzturbe ergibt, bas unriøtig ift.

Die ridtigen 3ablen von $1902-1912$;ind: 4,$6 ; 4,6 ; 4,8 ; 5,0 ; 5,1 ; 5,3 ; 5,6$; 5,$4 ; 5,3 ; 5,2 ; 5,1$.

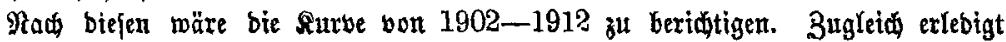

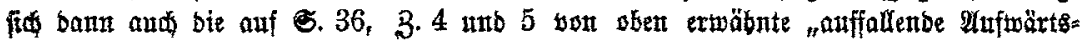
bewegung bon 1900 auf $1902^{4}$.

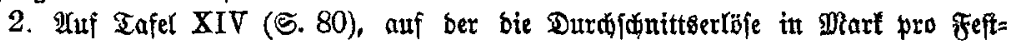

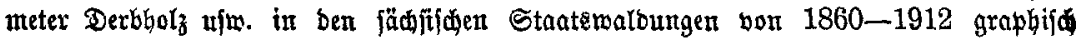
bargeftellf ftro, wurbe als Durdidnittgerlös pro Fefmeter Derbhols im Sabre 1900 15,9 und im Sabie 1906 16,1 .h aufgetragen; die riditigen Bablen find bezw. 16,9 und 15,1, wona bie Errösturve zu bertđtigen wäre.

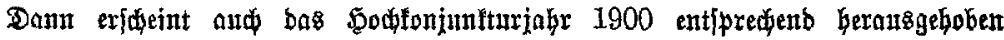
(f. S. 81 3. 1 von oben).

Dr. Rubaer.

\section{Ein forftliḑes (waldäjthetifhes) Preisausfdquetben}

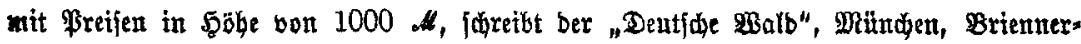

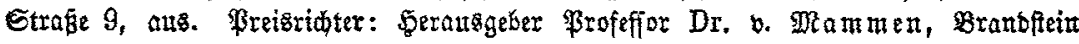

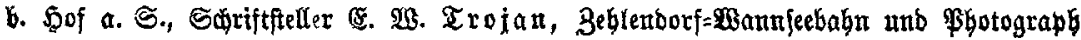
Miùllex, 5̧of a. S. Benaue Bebingungen burd ben Berlag.

\section{Gefthäftlią̧es.}

Sn ber heutigen Beitungs=Nummer finben Sie eine Inzeige ber großen Raü $=$ tabaffabril Cmil söller in Brndjal Baben. Dieje alte befante Fabrif verjenbet faon

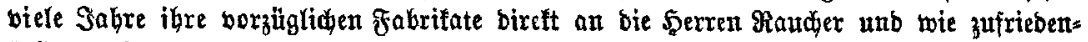

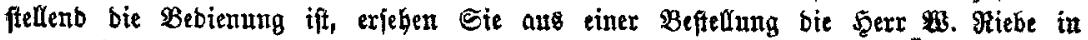

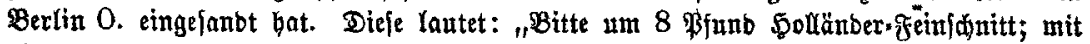

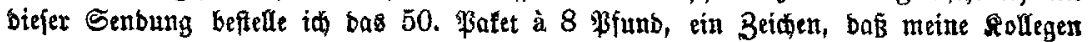

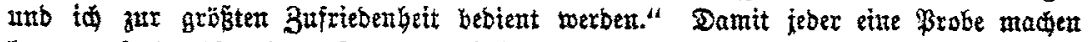

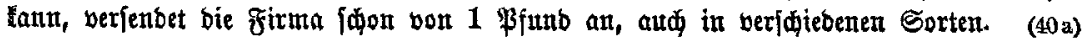

1) Sieb̆e Forftw. Eentralblatt 1920, \$. 453. 